\title{
A study of the clinico-anatomical variations in the shape and size of gallbladder
}

\author{
NADEEM, G. \\ Ajman University of Science and Technology, University Street, Al Jurf-1, PO Box 346, Ajman, United Arab Emirates. \\ *E-mail: g.nadeem@ajman.ac.ae
}

\begin{abstract}
Introduction: The structure and size of gallbladder, it's normal and a variation are forming an interesting field of study, and has gained importance Anatomically and Surgically. The gallbladder surgeries have drawn the attraction of surgeons because of lot of interesting and numerous variations present in them. Materials and Methods: The study was carried on 100 gallbladder from cadavers of all age groups. Results: In our study, the length of the gallbladder ranged from $4.5-11.6 \mathrm{~cm}$, breadth from $2.7-5.2 \mathrm{~cm}$. The shapes of the gallbladder varied from pear (82.85\%), Hartman's pouch $(7.14 \%)$, cylindrical $(2.86 \%)$, flask shaped $(2.86 \%)$, hour glass $(1.43 \%)$, bilobed $(1.43 \%)$ and irregular $(1.43 \%)$. Some gallbladders with mesentery $(1.30 \%)$ and horizontally placed $(4.30 \%)$ gallbladders were also found. Conclusion: The findings showed various anatomical variations pertaining to shape and position, which are to be taken into account for radiological study, Investigative procedures, surgical interventions, clinical implications and comparative anatomy.
\end{abstract}

Keywords: gallbladder, cystic duct, Hartman's pouch.

\section{Introduction}

The biliary tract is one of the most frequent sites of operative intervention, with an estimated 850,000 biliary tract procedures performed every year in our country. Cholecystectomy is the most common operative procedures performed on biliary tract. In the surgery of gallbladder, it is not so much the gallbladder itself, but it is the ducts and vessels that present the difficulties. Hence, both the normal anatomy and the high incidence of variations occurring in the relations between the vascular and the ductal systems must therefore be kept in mind.

Abnormalities in pattern of bile duct occur with sufficient frequency to be of importance during cholecystectomy. The location and pattern of the major bile ducts should be ascertained prior to removal of the gallbladder, to maintain the continuity of bile drainage from the liver into the duodenum. The aberrant and accessory bile ducts, either joining or forming major bile ducts should not be injured during surgery. Inadvertent trauma to either normal or aberrant bile ducts during operation may subsequently produce bile leakage, peritonitis, shock, fistula or ductal stricture thereby increasing the morbidity and mortality.

Sporadic cadaver and autopsy studies have repeatedly emphasized the variations that exists in the pattern of extrahepatic biliary apparatus by various anatomists (BOYDEN, 1926; HOLLINSHEAD, 1983; SHAHER, 2005; GROSS, 1936).

On laparoscopic visualization anatomical relations are seen differently than during conventional surgery. Therefore, proper knowledge of the hepatobiliary triangle and the structures closely related is most important.

\section{Methodology}

In the present study, a total no. of hundred livers with Extra Hepatic Biliary Apparatus along with hepatoduodenal ligaments, duodenum, and abdominal aorta with gallbladder was removed en-mass from cadavers of all age groups over a period of two years in the Dept of Anatomy, Shadaan Institute of Medical Sciences, Hyderabad. The chemicals used were absolute alcohol, xylene and formalin. The dissecting instruments included scalpel, blades, forceps, scissors, measuring tape, artery forceps etc. The specimens were preserved in $10 \%$ formalin. Bile duct, hepatic artery and portal vein were identified, separated and were traced up to their divisions at the Porta-Hepatis. The gall bladder was separated from the fossa of gall bladder and cystic duct was identified.

\section{Results}

The present study had following results:

\section{Dimensions of the gallbladder:}

a. Length of the gallbladder- The length of the gallbladder was found to be ranging between $4.5 \mathrm{~cm}-11.6 \mathrm{~cm}$. In 82 $(82 \%)$ it ranged between $6 \mathrm{~cm}-9.5 \mathrm{~cm}$. The findings are depicted in Table 1 and Figures 1-3

b. Breadth of the gallbladder. The breadth of the gallbladder varied between $2.7-5.2 \mathrm{~cm}$. In 45 (45\%) the value ranged from 3.2-4.7 cm. The findings are given in Table 2 and Figure 4 .

\section{Shapes of the gallbladder}

Different shapes of the gallbladder were seen:
a/ Pear shaped $-82.85 \%$ (58)
b/Hartman's pouch - 7.14\% (5)
c/ Cylindrical $-2.86 \%(2)$ 
Table 1. Variations in the length of the gallbladder.

\begin{tabular}{cccc}
\hline S. No & $\begin{array}{c}\text { Length in } \\
\mathbf{c m}\end{array}$ & $\begin{array}{c}\text { No. of } \\
\text { specimens }\end{array}$ & Percentage \\
\hline 1. & $4.5-6$ & 5 & $8 \%$ \\
2. & $6-9.5$ & 58 & $82 \%$ \\
3. & $9.5-11.6$ & 7 & $10 \%$ \\
\hline
\end{tabular}

Table 2. Variations in the breadth of gallbladder.

\begin{tabular}{cccc}
\hline S. No & $\begin{array}{c}\text { Breadth in } \\
\text { cm }\end{array}$ & $\begin{array}{c}\text { No. of } \\
\text { specimens }\end{array}$ & Percentage \\
\hline 1. & $2.5-3.2$ & 8 & $11.43 \%$ \\
2. & $3.2-4.2$ & 50 & $71.43 \%$ \\
3. & $4.2-5.1$ & 12 & $17.3 \%$ \\
\hline
\end{tabular}

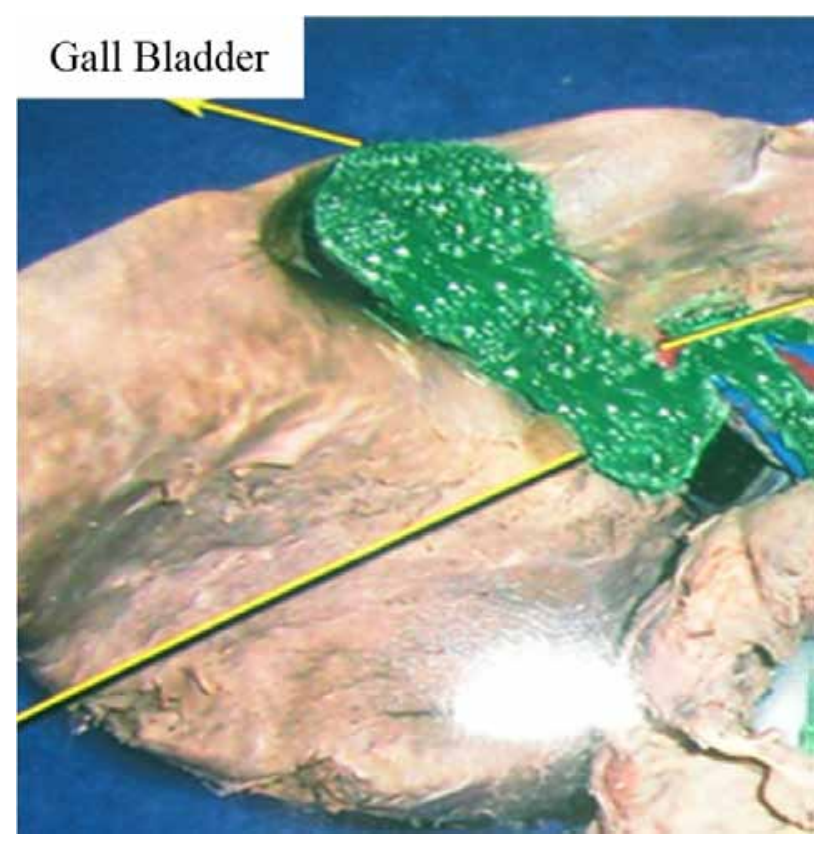

Figure 1. Normo gall bladder.
d/Flask shaped $-2.86 \%(2)$
e/ Hourglass - $1.43 \%$ (1)
f/ Bilobed $-1.43 \%(1)$
$\mathrm{g} /$ Irregular - $1.43 \%(1)$

These variations are depicted in Table 3 and Figures 5-11.

\section{Other Morphological Variations:}

a/ Gallbladder with mesentery was seen in $1.30 \%$ specimens.

b/Horizontally placed gallbladder was found in $4.30 \%$ specimens. These changes are depicted in Table 4 and Figures 12 and 13.

\section{Discussion}

The liver, gallbladder and the biliary ductal system develop from the hepatic diverticulum of the foregut, in the beginning of the $4^{\text {th }}$ week of development. This diverticulum rapidly
Table 3. Variations in the shapes of gallbladder.

\begin{tabular}{cccc}
\hline $\begin{array}{c}\text { S. } \\
\text { No }\end{array}$ & $\begin{array}{c}\text { Shapes of the } \\
\text { gallbladder }\end{array}$ & $\begin{array}{c}\text { No. of } \\
\text { specimens }\end{array}$ & Percentage \\
\hline 1. & Pear & 58 & $82.85 \%$ \\
2. & Hartman's pouch & 5 & $7.14 \%$ \\
3. & Cylindrical & 2 & $2.86 \%$ \\
4. & Flask shaped & 2 & $2.86 \%$ \\
5. & Hour glass & 1 & $1.43 \%$ \\
6. & Bilobed & 1 & $1.43 \%$ \\
7. & Irregular & 1 & $1.43 \%$ \\
\hline
\end{tabular}

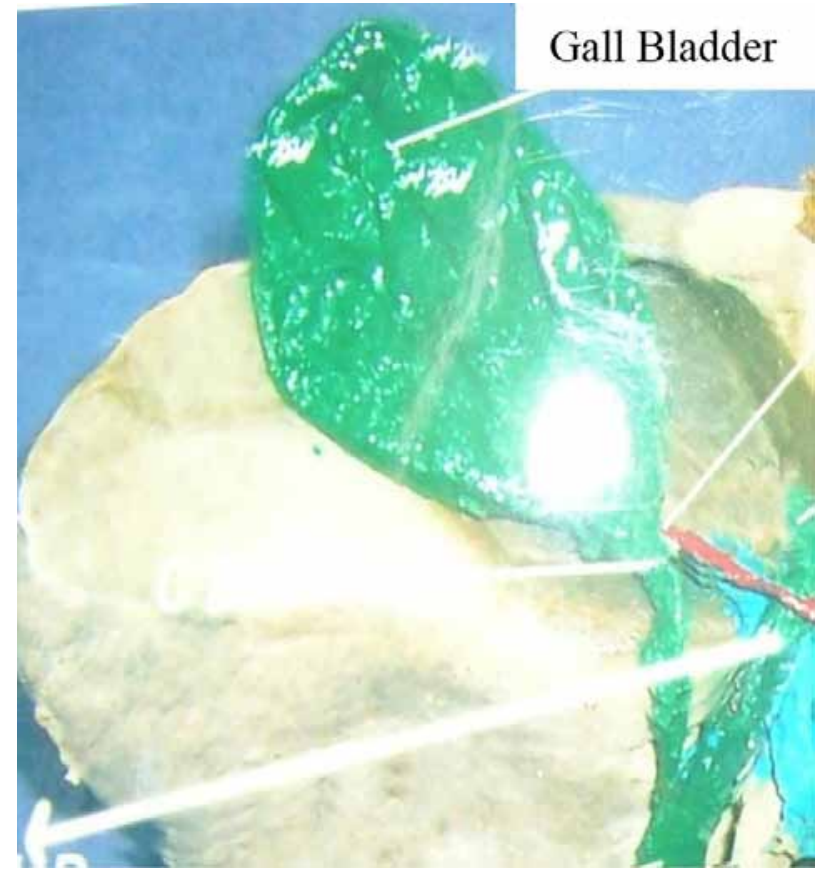

Figure 2. Increased length of gall bladder.

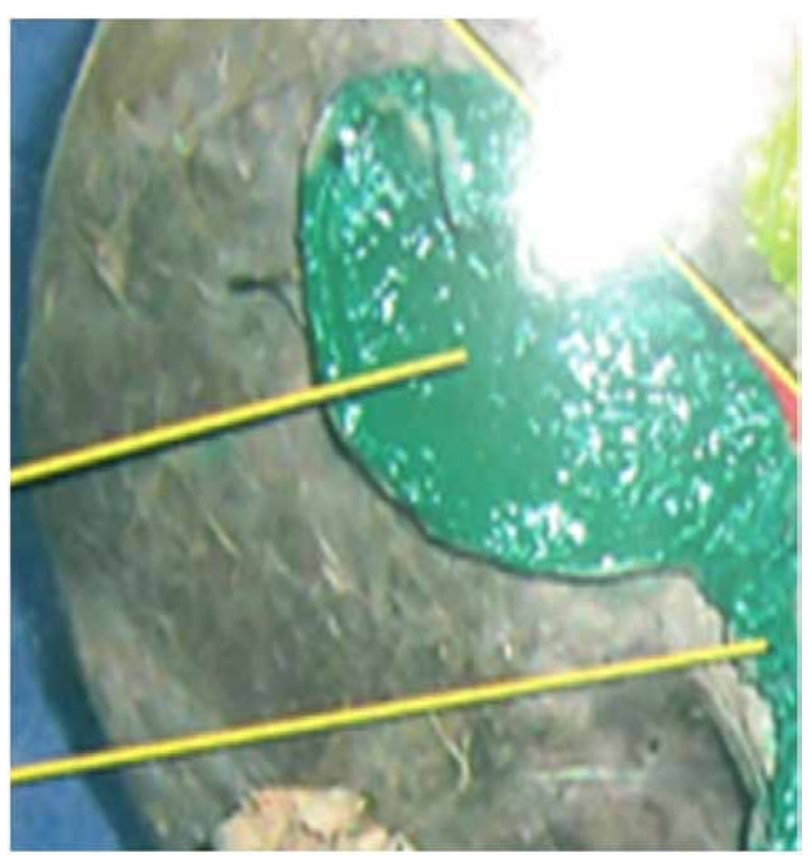

Figure 3. Decreased length of gallbladder. 


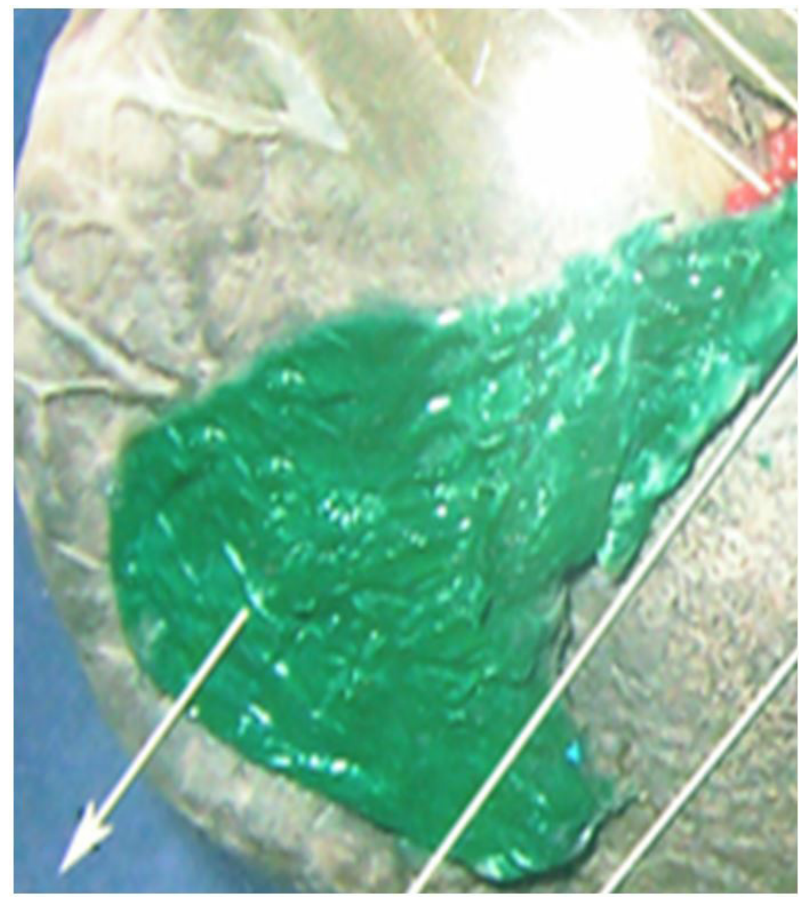

Figure 4. Increased breadth of the gallbladder.

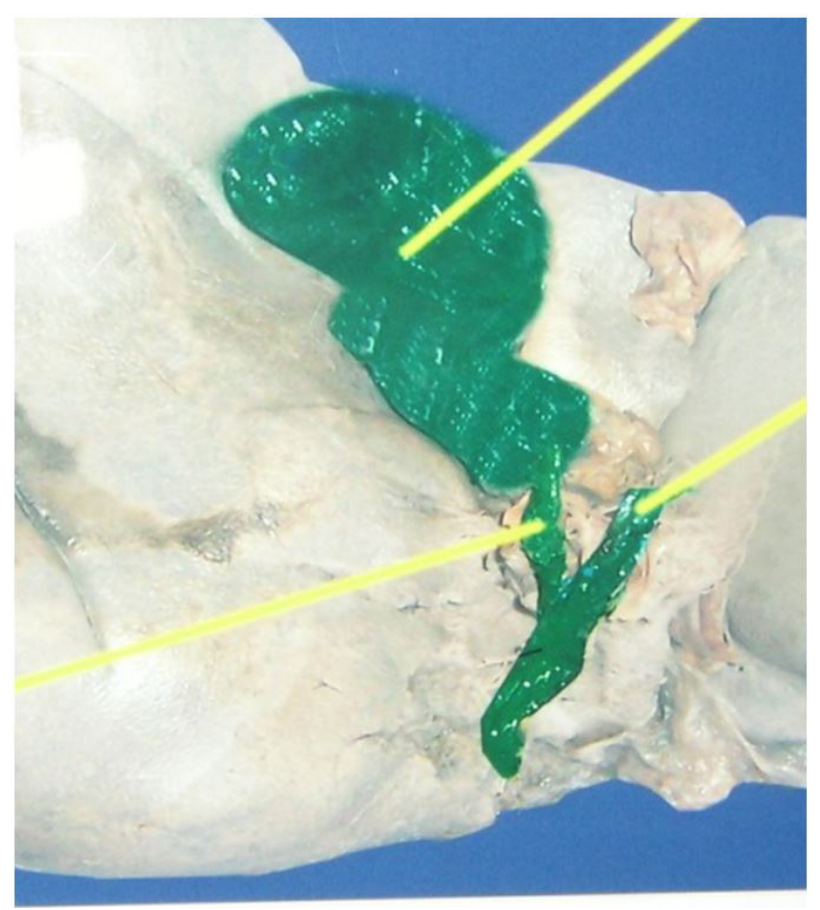

Figure 5. Hourglass gall bladder.

proliferates into the septum transversum and divides into two parts; the cranial part gives rise to the liver and bile ducts while the caudal part gives rise to gallbladder and the cystic duct. Initially the extrahepatic biliary system is occluded with epithelial cells, but later on, it gets canalized due to subsequent degeneration of these cells. Thus, it is very probable that any arrest or deviation from the normal embryological development may result in some sort of malformation of the gallbladder and the biliary system.

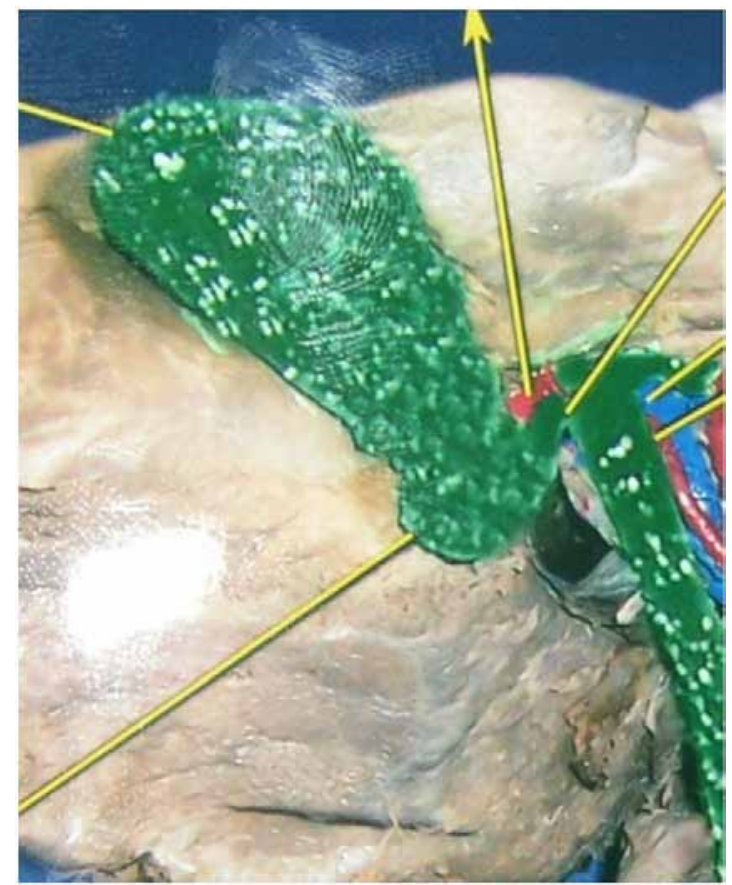

Figure 6. Hartman's pouch in gallbladder.

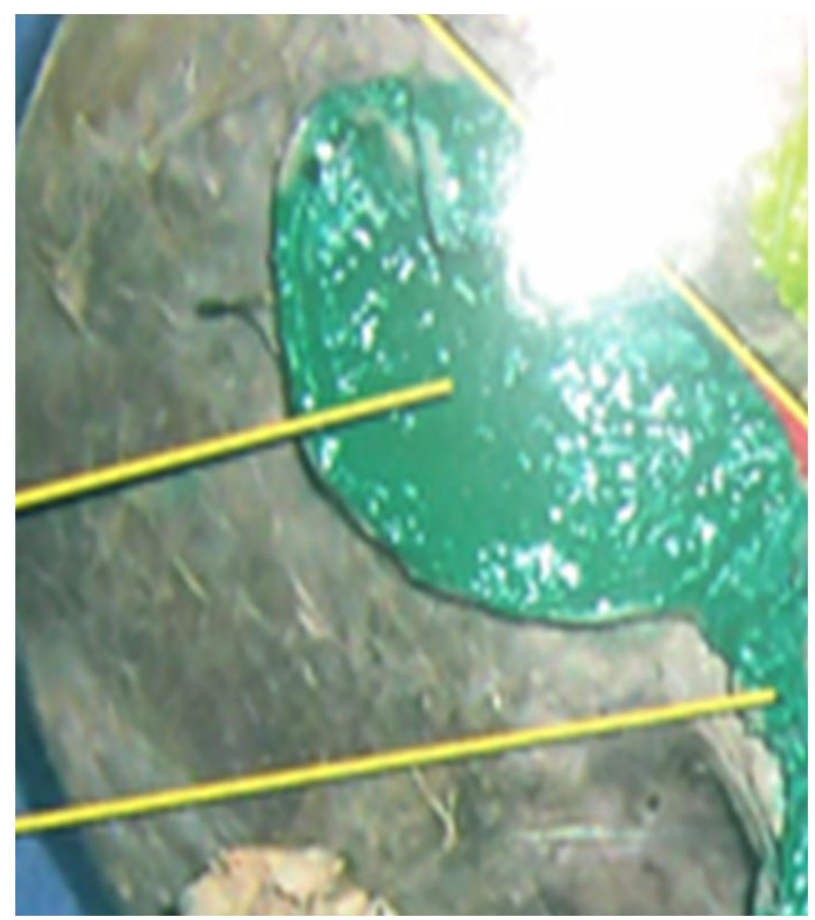

Figure 7. Pear shaped gallbladder.

Table 4. External variations of the gallbladder.

\begin{tabular}{clcc}
\hline S.No & \multicolumn{1}{c}{ Variation } & $\begin{array}{c}\text { No. of } \\
\text { specimens }\end{array}$ & Percentage \\
\hline 1. & $\begin{array}{l}\text { Gallbladder } \\
\text { with mesentery }\end{array}$ & 1 & $1.43 \%$ \\
2. & $\begin{array}{l}\text { Horizontally } \\
\text { placed } \\
\text { gallbladder }\end{array}$ & 3 & $4.3 \%$ \\
\hline
\end{tabular}


The gallbladder varies greatly in size and shape and hence sometimes impossible to distinguish between various parts.

1. Length of the gallbladder: The length of the gallbladder was found to be ranging between $4.5 \mathrm{~cm}-11.6 \mathrm{~cm}$. In 82 $(82 \%)$ it ranged between $6 \mathrm{~cm}-9.5 \mathrm{~cm}$. The findings in the present study were consistent with those of Rajguru, Khare, Jain et al. (2012) but were a little different from

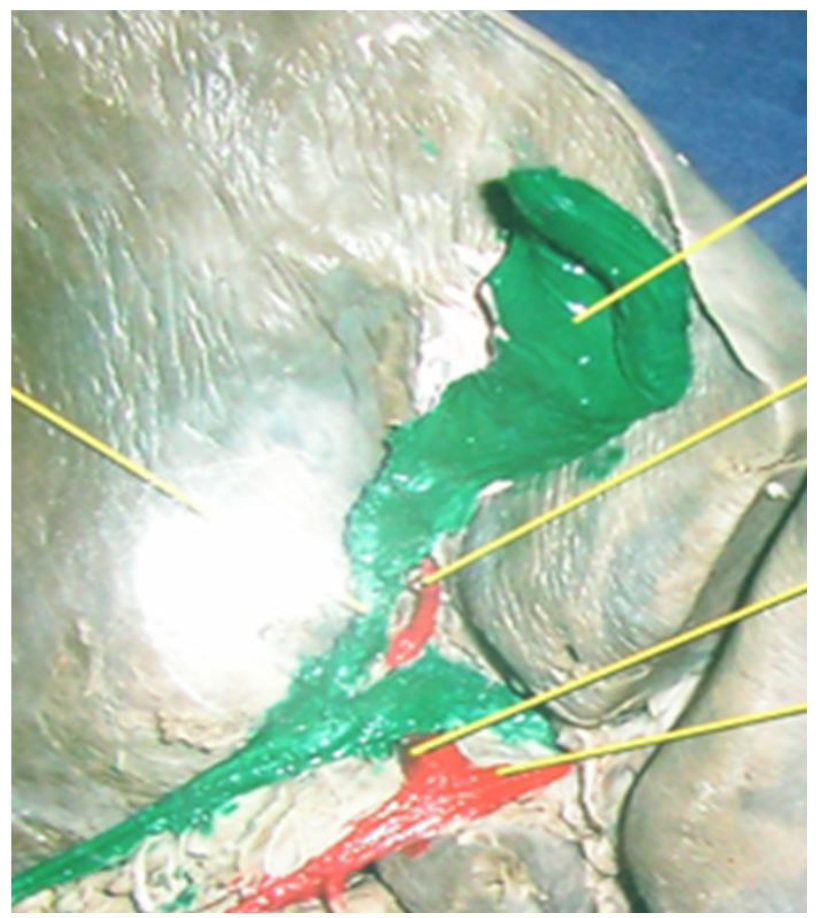

Figure 8. Flask shaped gallbladder.

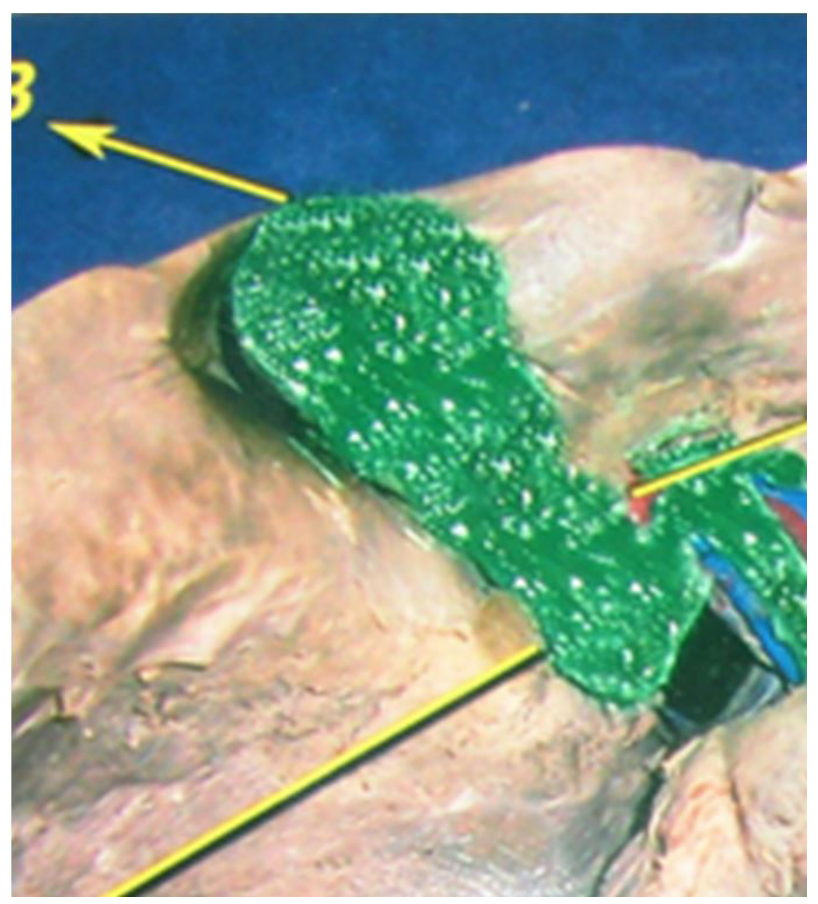

Figure 9. Cylindrical gallbladder.

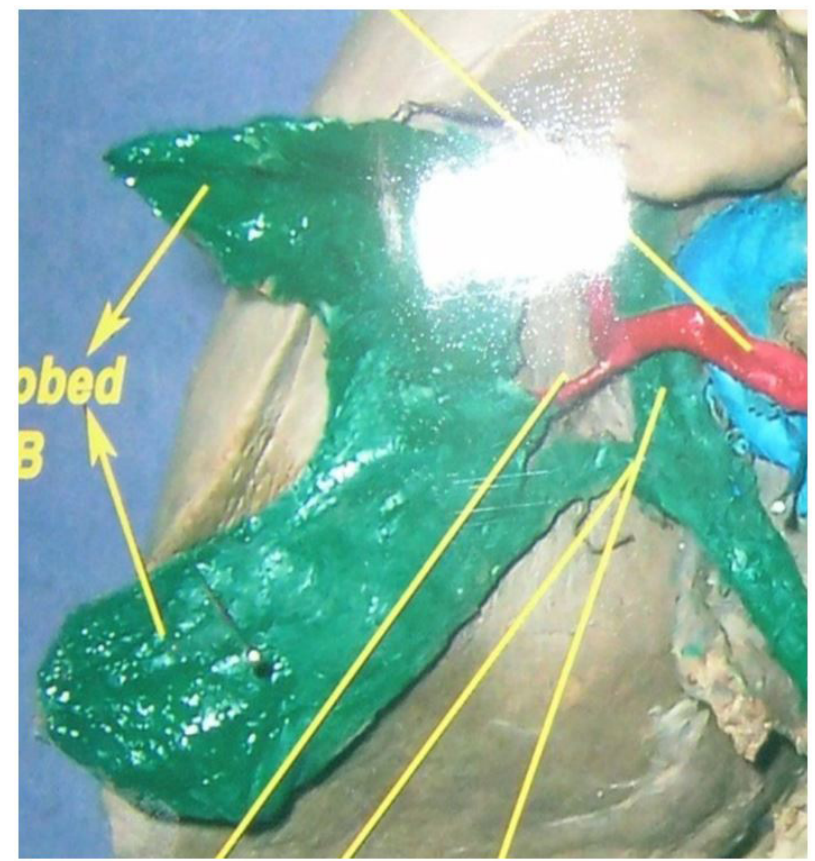

Figure 10. Bilobed gallbladder.

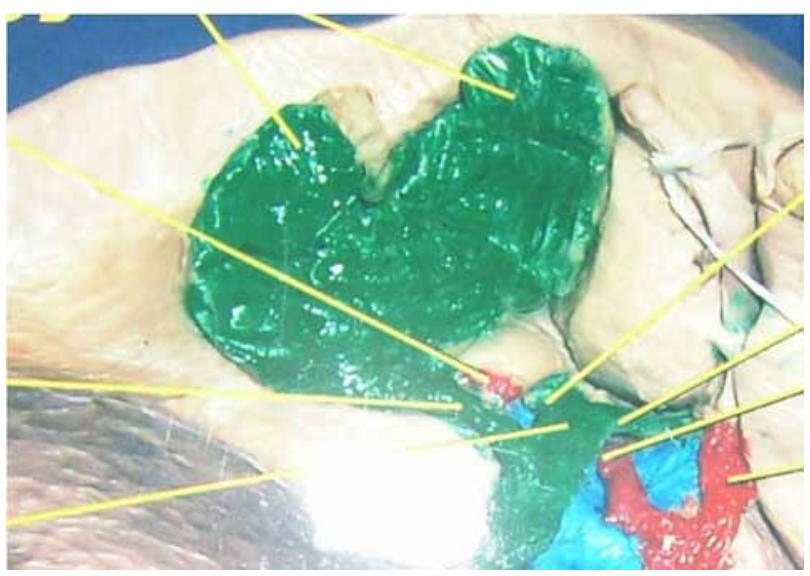

Figure 11. Irregular shaped gallbladder.

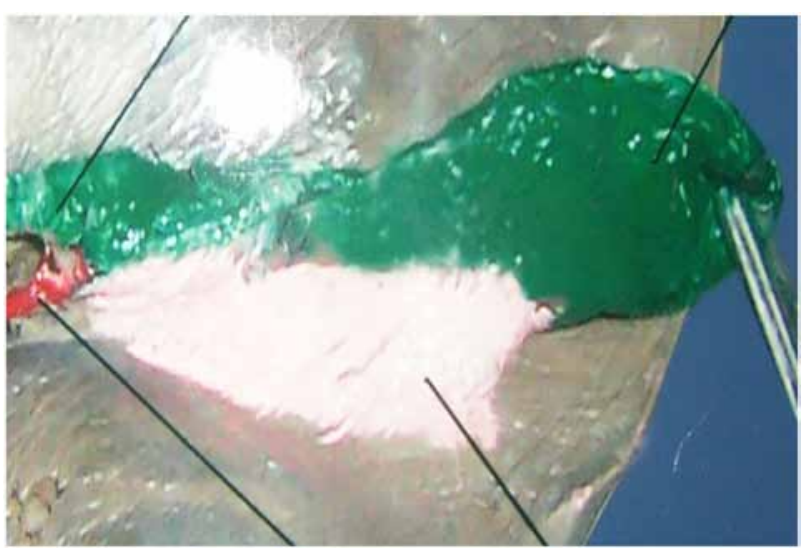

Figure 12. Gallbladder with mesentry. 
others may be due to racial differences. These findings are shown in Table 5 .

2. The breadth of the gallbladder varied between $2.7-5.2 \mathrm{~cm}$. In $45(45 \%)$ the value ranged from $3.2-4.7 \mathrm{~cm}$. This value was consistent with that of Rajguru, Khare, Jain et al. (2012), Chari and Shah (2008) and Turner, Fulcher, Gore et al. (2000). Some workers like Gore, Fulcher, Taylor et al. (2000) have reported that size might increase after vagotomy, in diabetes due to autoimmune neuropathy, in pregnancy, in patients with sickle cell disease and in extreme obese people whereas micro-gallbladder was seen in patients with cystic fibrosis. These findings are shown in Table 5.

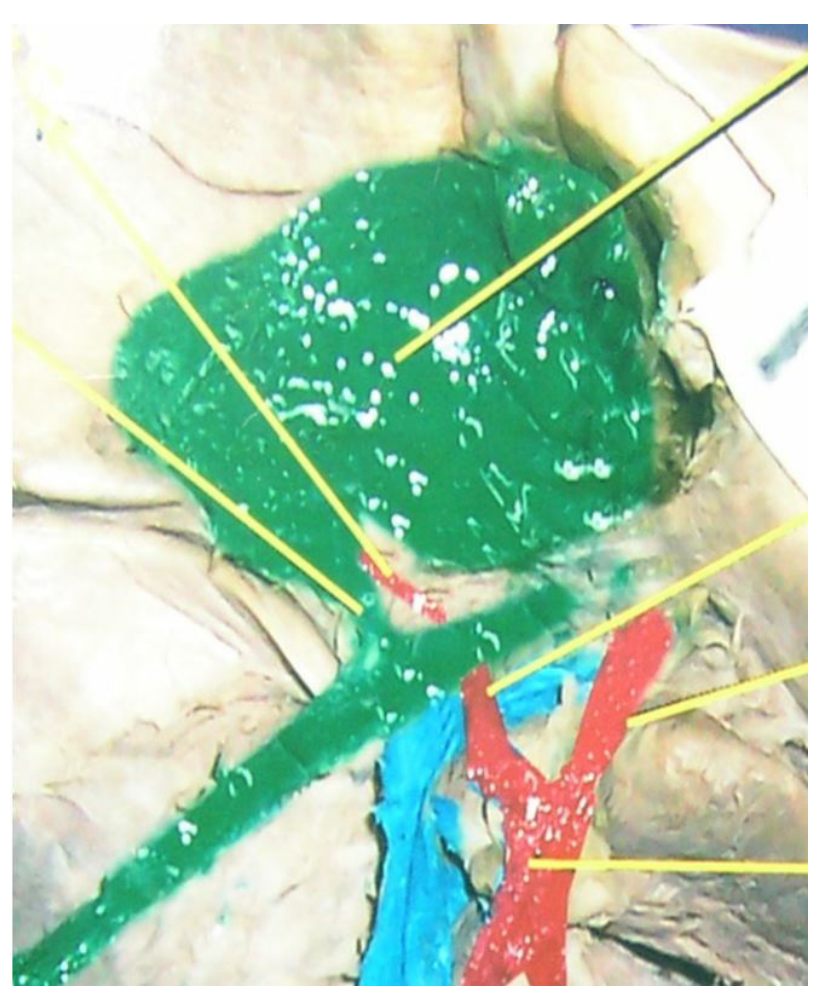

Figure 13. Horizontally placed gallbladder.
3. The shape of the gallbladder: Pear shape is the most common $(82.85 \%)$, which is in consonance with the findings of Rajguru, Khare, Jain et al. (2012), Moore and Dalley (2006) and Chari and Shah (2008). Cylindrical shape has been observed by Rajguru, Khare, Jain et al. (2012) in $3.33 \%$ cases while in the present study it is $2 \%$ only. The flask shape has also been reported by Rajguru, Khare, Jain et al. (2012) in 5\% cases while in the present study it is $2 \%$. Also there was presence of Irregular shaped gallbladder which was present in $1.67 \%$ cases by Rajguru, Khare, Jain et al. (2012) while in the present study it was $1.43 \%$ which was almost similar. These findings are shown in Table 5.

4. Hollinshead(1983), McGregor (1986), Keith Moore (2006) and Standring (2008), described the presence of Hartmann,s pouch as a constant feature. It is considered by few as pathological, but such percent wise study was not done. Ejick, Veen, Lange et al. (2007) has documented that Hartmann's pouch is a morphological entity and not an anatomical entity. Futura and Kinfu (2001) observed higher prevalence of Hartman's pouch in females than males. In the present study, Hartmann's pouch is present in $10 \%$ of the specimens.

5. Presence of Hourglass gallbladder: First time in 1890, It is observed as a constriction at the junction of middle and lower third of gallbladder, which divides the gallbladder into a wider upper zone and a smaller lower portion. Courvoisier (1890) reported the hourglass gallbladder as a cicatrical contraction secondary to inflammation. It was also described by Boyden (1926), Gross (1936) and Shaher (2005) but percentage was not reported. Rajguru, Khare, Jain et al. (2012) had an incidence of $3.33 \%$ while in the present study, hourglass gallbladder is seen in $1 \%$ of the specimens.

6. Presence of Bilobed gallbladder: Courvoisier (1890) reported the first human case of bilobed gallbladder. In the present study, bilobed gallbladder is seen in $2 \%$ of cases.

7. Floating gallbladder: It is when gallbladder is covered by the peritoneum on all sides and is suspended from the inferior surface of the liver by a fold of mesentery in

Table 5. Comparison of length, breadth and shape with observations of other workers.

\begin{tabular}{|c|c|c|c|c|}
\hline S.No & Researcher/Year & Length $(\mathrm{Cm})$ & Breadth $(\mathrm{Cm})$ & Shape \\
\hline 1 . & $\begin{array}{l}\text { Lee McGregor, Decker and Plessis } \\
(1986)\end{array}$ & $7.5-10$ & - & - \\
\hline 2. & Turner, Fulcher, Gore et al. (2000) & 10 & $3.0-5.0$ & Elliptical \\
\hline 3. & Moore and Dalley (2006) & $7-10$ & - & Pear shaped \\
\hline 4. & Chari and Shah (2008) & $7-10$ & $2.0-5.0$ & Pear shaped \\
\hline 5. & Vakili and Pomfret (2008) & $7-10$ & 4.0 & Piriform \\
\hline 6. & Standring $(2008)$ & $7-10$ & - & Flask shaped \\
\hline 7. & Rajguru, Khare, Jain et al. (2012) & $5-12$ & $2.5-5.0$ & $\begin{array}{c}\text { Pear }(85 \%), \text { Flask }(5 \%), \text { Cylindrical } \\
(3.33 \%), \text { Hourglass }(3.33 \%), \text { Retort (1.67\%), } \\
\text { Irregular }(1.67 \%)\end{array}$ \\
\hline 8. & Present Study & $4.5-11.6$ & $2.5-5.0$ & $\begin{array}{c}\text { Pear }(82.85 \%), \text { Hartman's pouch }(7.14 \%), \\
\text { Cylindrical }(2.86 \%) \text {, Flask shaped }(2.86), \\
\text { Irregular }(1.43 \%), \text { Hour-glass }(1.43 \%), \\
\text { Bilobed }(1.43 \%)\end{array}$ \\
\hline
\end{tabular}


$5 \%$ of the specimens. In the present study, the percent of floating gallbladder is $1 \%$. It makes the gallbladder liable to undergo torsion and hence ischaemia.

8. Position of Gallbladder: Various ectopic positions of the gallbladder as intrahepatic, suprahepatic or gallbladder in the internal oblique muscle has been observed but horizontally placed gallbladder in the fossa for gallbladder has not been reported. In our study, it is seen in 3\% specimens. This is a noticeable observation and must be taken into account while considering surgical intervention of gallbladder.

\section{Conclusion}

In the present study of 100 specimens the findings showed various Anatomical variations pertaining to Gallbladder shape and position which are to be taken into account for Radiological study, Investigative procedures, Surgical interventions, Clinical Implications, Embryological explanations and Comparative anatomy. Refinements in operative and diagnostic techniques demand a detail knowledge of Anomalies. Therefore, there should be closer co-operation between the operating room, anatomy laboratory and pathology labs. As the laparoscopic cholecystectomies are increasing, clear knowledge of the gallbladder variations is critical.

Thus, an Anatomist plays an important role to find out these anatomical variations and make difficult operations easy, to prevent post-operative complications and thus reducing morbidity and mortality.

\section{References}

BOYDEN, EA. The accessory gallbladder: an embryological and comparative study of aberrant biliary vesicles occuring in man and domestic animals. The American Journal of Anatomy, 1926, vol. 38, p. 177.

CHARI, RS. and SHAH, SA. Sabiston textbook of surgery in biliary system. 18th ed. St. Louis: WB Saunders, 2008. chap. 54, p. 1474-1514.

COURVOISIER, L. Casvistich-statistische beitrage zur pathologie und chirugie der gallenwege. 1st ed. Leipzig: Verlag von F.C.W. Vogel, 1890.
EJICK, V., VEEN, V., LANGE, J.F., KLEINRENSINK, G.J. Hartman's gallbladder pouch revisited 60 years later. Surgical Endoscopy: Surgical e Interventional Techniques, 2007, vol. 2, n. 7, p. 1122-1125.

FUTURA, G., KINFU, Y. Anatomical variations of gallbladder and biliary ducts among Ethiopians. Ethiopian Medical Journal, 2001, vol. 39 , n. 3 , p. 173-84.

GORE, RM., FULCHER, AS., TAYLOR, AJ. and GHAHREMANI, GG. Textbook of gastrointestinal radiology in anomalies and anatomic variants of the gallbladder and biliary tract. 2 nd ed. Philadelphia: WB Saunders, 2000. p. 1305-1320.

GROSS, RE. Congenital anomalies of gallbladder: review of 148 cases with report of double gallbladder. Archives of Surgery, 1936, vol. 32, p. 131-162.

HOLLINSHEAD, WH. Anatomy for surgeons in the liver and the gallbladder. 3rd ed. Philadelphia: Harper and Row, 1983. vol. 2, 334 p.

LEE MCGREGOR, A., DECKER, GAG. and PLESSIS, DJD. Lee

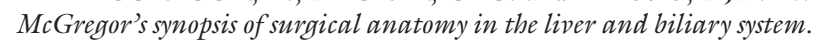
12th ed. Bombay: KM Verghese and Company, 1986. p. 78-103.

MOORE, KL. and DALLEY, AF. Clinically oriented anatomy in abdomen. 5th ed. Philadelphia: Lippincott Williams \& Wilkins, 2006. 302 p.

RAJGURU, J., KHARE, S., JAIN, S., GHAI, R., SINGLA, M. and GOEL, P. Variations in the external morphology of gallbladder. Journal of Anatomical Society of India, 2012, vol. 61, n. 1, p. 9-12.

SHAHER, Z. Gallbladder Anomalies; Agenesis, hourglass and liver tissue migration: a multimedia Article. The Internet Journal of Surgery, 2005 , vol. 7 , p. 1.

STANDRING, S. Gray's Anatomy: the anatomical Basis of clinical practice in gallbladder and biliary tree. 40th ed. Philadelphia: Elsevier Churchill Livingstone, 2008. chap. 69, p. 1177-1181.

TURNER, MA., FULCHER, AS., GORE, RM. and LEVINE, MS. Textbook of gastrointestinal radiology in gallbladder and biliary tract: normal anatomy and examination techniques. 2nd ed. Philadelphia: WB Saunders, 2000. vol. 2, p. 1250-76.

VAKILI, K. and POMFRET, EA. Biliary anatomy and embryology. Surgical Clinics of North America, 2008, vol. 88, n. 6, p. 1159-1174.

Received Augusut 12, 2014

Revised June 10, 2015

Accepted June 15, 2016 